\title{
GENRE SPACE OF FOLK NARRATIVE TRADITION: THE RUSSIAN CASE
}

\author{
Georgiy A. Levinton
}

\begin{abstract}
In this paper I intend to present the "narrative part" of a larger study, Genre Space of Traditional Russian Folklore (or Ethnopoetry, Oral Poetry), which is described in its entirety elsewhere. Two main dimensions (axes, distinctive features) of the space are (a) versified vs. non-versified (verse in Russian folklore, as in some others as well, means sung or recitative performance), and (b) prosaic vs. non prosaic, where prose actually means 'a story', i.e., narrative. Thus we have four groups of genres: (1) narrative in verse, (2) non-versified narrative (prose sensu stricto), (3) non-narrative verse (lyrical song, laments) and (4) "neither verse nor prose" (paroemia, spells, etc.).

The structure of the two narrative groups is mainly symmetrical; each of them has one nuclear genre, a "main" or most representative genre (fairy tale in non-versified genres, and bylina (epics) in versified ones) and peripheral genres, largely corresponding to each other. The category of 'spiritual verses' (dukhounyie stikhi) corresponds to sacred legends (both being sacral genres), although their repertory of tale types is quite different (e.g., non-versified oral legend includes no hagiographic legends, vitae). Historical songs (some historical ballads as well) share common subject matter with historical legends (istoricheskoe predanie - tales about historical persons). Ballads roughly correspond to novelles (usually called novelistic or Romantic tales, AaTh 850-899), while comic or parody epics resemble the "Jokes and Anecdotes" of Aarne's classification. For many European traditions I might mention Animal Tales and Animal Epics, respectively, but Russian tradition has no animal epics in verse. Each group has one feature that diminishes as one moves from the nuclear genre to the peripheral ones; in verse genres, this is verse itself. Epics are sung in bylina (epic) verse; other genres combine epic verse and song-verse. In non-versified texts this feature is a stylistic elaboration, with special formulas which can be found to a most sophisticated degree in fairytales and are much less prominent in other genres. Some other types of symmetry connect these genres with non-narrative ones.
\end{abstract}

Key words: genre space of folklore, Russian folklore, versified vs. non-versified genres, prosaic vs. non-prosaic genres

The description of the genre space of Russian Folklore, ${ }^{1}$ or rather its narrative segment ${ }^{2}$ to be offered here is not a strict classification devised and intended to avoid any overlapping of classes. Neither it is a "new classification", in the sense that I have no intention to come "back to basics", to take the raw con- 
tinuum of texts and suggest new borders for them, thus defining genres anew. ${ }^{3}$ I will operate with and discuss genres as traditionally defined (listed in most textbooks or, for instance, in Vladimir Propp's works on genres of the Russian Folklore tradition (Propp 1976a; 1976b)). These familiar and traditional genres will be used as units of the structure to be described here, and it will be their arrangement that I intend to describe. I believe, though, that it is not just a Glasperlenspiel. As an unrepentant structuralist I believe the genres are real entities, not just constructs invented by us, and by discussing their interrelation, their distinctive features and thus, the arrangement of the genre space, we can learn something about their nature.

I postulate that two main distinctive features (DF) or, in other words, axes of the genre space are (1) versified vs. non-versified (2) prosaic vs. non-prosaic. These DF are not complementary, and non-versified does not mean prosaic. In folklore versified actually means 'sung' whether that refers to actual singing or to a recitative performance like in epics (bylinas) or laments. ${ }^{4}$ Nonversified, naturally, means all genres that are not sung but retold, pronounced (e.g., blessings or curses), cried out (announcements of street peddlers), etc. Prose is something to be retold; prose is not just any non-versified speech, but a story, i.e., a narrative. I suppose that anyone more or less acquainted with folkloristic usage would agree that it is the standard way in which the term prose is used and understood (I suppose, not only in Russian). So non-prosaic does not mean verse, but any non-narrative text. ${ }^{5}$

I am aware that for many theorists, these $\mathrm{DF}$ would not be acceptable for a number of reasons. They believe that the verse or prosaic rendering of a motif is just a chancy and irrelevant trait of performance (cf. some notes on the problem below). Yet I do not try to suggest that they are a basis for the universal genre system. This description is just a case study, so to say, a traditionspecific approach; in other words, I claim this description is adequate only for Russian folk tradition and I would not presume to apply it to other cases. It is well known that descriptions of genre systems can be universally oriented (or at least typologically oriented) and specifically oriented, the extreme cases of the latter being descriptions that use only native genre definitions or terms. ${ }^{6}$ My attempt belongs to the later type, with the slight difference that I am listening not to native performers but to native scholars.

Thus we have four large groups of genres:

1. Verse $+\&$ Prose - .There we found songs (usually named lyric songs, that is non-narrative sung texts) and laments (in Russian tradition: funeral, wedding and so-called conscript laments, performed at seeing off the conscripts, as well as a very small number of laments on other occasions), in the 19th century chastushka 'ditty' is added. ${ }^{7}$ 
2. Verse $+\&$ Prose + . This is the domain of narrative poetry: epics (bylinas), ballads, historical songs (which, quite differently from epic songs, usually contain no supernatural element and deal with more recent periods than epics do), dukhounye stikhi (lit. 'spiritual verses', narrative songs on sacred matters), ${ }^{8}$ and skomoroshiny, parodic epics. ${ }^{9}$

3. Verse $-\&$ Prose + . That is what is traditionally named folk prose, all nonversified narrative genres including folktales, legends, sacred legends, demonic legends, etc. Russian folklore scholars usually (with a few dissent voices) divide these genres into skazki ('folktales') - the group of genres with a common feature of fictionality (that includes fairy tales, animal tales, novellas and jokes), and so-called neskazochnaia proza ('non-folktale' = 'non-fictional prose') comprising sacred legends (Russ. legenda), historical tales (in part correspond to local legends, in part, maybe, to chronicles - Russ. term istoricheskie predaniia [plural], literally meaning 'historical traditions', implies that each story is a separate 'tradition', 'that which has been handed down'), demonic legends (Russ. bylichka), gossip and rumors, and probably some other minor varieties.

4. Verse - \& Prose -. This domain includes all non-narrative genres that are not sung. They include first of all spells or incantations, proverbs and riddles and some less prominent paroemiac genres. ${ }^{10}$

Many scholars claim that proverbs and riddles are versified genres. I cannot agree: First, because there are too many exceptions to consider verse as a genre-defining feature (actually it is not really the verse they ascribe to proverbs but only a rhyme, see below), and secondly, because rhymed proverbs of the same types can be found in different languages with quite different systems of versification, so they are not in fact the phenomena of versification in each of these languages, but of some different nature (that is the argument by Mikhail L. Gasparov, see references below). But even if we would agree to discard these genres as non-versified, there are several other genres belonging to this area that are usually described as composed in so-called "spokenverse" (govornoi stikh, or raioshnyi stikh), that is the kind of "verse" that has only one verse feature, namely rhyme (frequently caused by parallelism). It consists of "lines" (or colons) with any number of syllables and arbitrary placement of stresses, united only by rhymes. From the point of view of literary perception of the 19th and 20th century it can be seen as verse, but originally, and that is the most important reason, in Russian folk as well as early literary tradition rhyme could not function as a symptom of verse. In traditional folklore, before the late 17 th century, Russian folk verse was invariably blank. Just like it was in Greek literature, rhyme was the feature not of verse, but of 
prose, namely, rhetorical prose, and that is the only adequate description for such genres as speeches of the best man at a wedding or the showman at a fair (I follow here Mikhail Gasparov 1989: 34-37, cf. also Toporov 1998: 214-216). The rhyme could not be perceived as a feature of verse before the 17th century, when the acquaintance with Polish syllabic verse took place. In some forms like chastushka ('ditty') that arose only in the 19th century, we do have rhymed verses, which means that some changes could have occurred within the folk tradition as well, but that could only happen long after "spoken verse" had begun to be perceived as a verse. I cannot dwell on this question in detail, since it does not belong to the domain of narrative genres, but I will have to refer to this part of our genre-space in my subsequent argument.

Thus the narrative part of Russian genre space consists of two groups: (2) verse $+\&$ prose + and (3) verse $-\&$ prose + , in other words, versified and non-versified narrative genres.

The two narrative groups of genres show significant symmetry. In each group there is a genre that stands out as the most representative, the most important and, at the same time, the most structured one. For versified genres, it is the most elaborated and most prestigious among these genres, that is the epic song traditionally named bylina ${ }^{11}$ For non-versified ones, it is clearly the Fairy-Tale that has the clear-cut morphological structure which Isaak I. Revzin (1975) interpreted as a paradigm of coherency.

Beside this main genre, each group has several peripheral genres, which, between the two groups, more or less correspond to each other. That is a pair of sacred genres: Dukhounye stikhi ('spiritual verses') resp. sacred legends (legendy); a pair of historical genres: historical songs resp. "historical legends"; a pair of comic genres: jokes and parodic epics (skomoroshiny). Much less resemblance can be found between ballads and novelles (or, as we usually name it, novelistic folktales); only some tale types could be compared with some kinds of ballads. And the most conspicuous is the lack of a counterpart for the animal folktale, since Russian tradition, unlike some European ones, has no animal epic. ${ }^{12}$ In the same way gossip and rumors have no narrative verse counterparts (one can compare them with chastushka which can relate (to) a fresh gossip or rumor, but chastushka, a short song usually in four lines, could hardly be described as a narrative genre).

Here one must stop to consider an alternative solution (the very symmetry I am describing could suggest it), namely: should we describe, as I do, prosaic or narrative genres as two groups of genres distinguished by the feature "versified vs. non-versified", or as a single group where the same genres have two kinds of formal representation, i.e., in a verse form and in a non-verse (traditionally speaking, prosaic) form. A proponent of a typological or strictly narrato- 
logical point of view would, I believe, prefer the last solution (my habitual opponent in this question is Heda Jason, whom I am glad to thank for many informal discussions). Probably for some traditions it would be preferable, but in our case I still would claim that the other alternative is better. First of all, I would prefer it to be a uniform solution, a single principle for all genres in question. Even if we agree to describe dukhovnye stikhi as a versified version of the genre of legend, ${ }^{13}$ still I doubt that similar solution would be acceptable for ballad and novelle, respectively, and even less - for jokes or comic tales in the non-verse group, and for parodic epic songs (even in broader sense), on the side of versified genres. Historical songs may sometimes resemble historical legends (or historical traditions); at least in their main narrative motifs, but many examples of this genre show no external resemblance to their non-versified counterpart, except for some historical names mentioned. This kind of historic songs have only rudimentary narration and probably should be subclassified within the genre as some kind of a non-narrative variety of historical songs, just as we distinguish a group of non-narrative dukhovnye stikhi within the genre. So, the argument of "uniformity" is clearly in favor of my solution, i.e., treating these two groups as different genres. Secondly, I believe that the logic of this paper also supports this solution.

So I suppose we should not try to unite these genres, but consider versified and non-versified texts as different genres with many thematic, narrative, semantic and poetic differences. Their symmetry belongs to a rather abstract level, a correspondence between sacred genres, historic ones, comic ones and "romantic" ones (the last refers to the case of slight resemblance between ballads and novelles), and moreover the symmetry is not complete (see, e.g., animal tales). Still this symmetry consists not solely of the correspondences between genres of similar thematic classes, but the very structures of both groups are arranged by similar principles. Each of the two groups has a single distinctive feature that is represented with the maximal strength in the "central", "main" genre of the group and is diminishing when we move from the center to the periphery.

In the non-versified group this feature is stylistic ornamentation and verbal formulas, sometimes very elaborated and lengthy. Scholars studying folktales almost unanimously claim that this technique is at its best in fairy tale (volshebnaia skazka). ${ }^{14}$ Some stylistic coloring can be found in some kinds of novelles (by their structure closest to fairy tales but usually without a miraculous element and with ample borrowings from popular literature). Much simpler in retelling and having a few or no formulas are other kinds of folktales, including animal tales. ${ }^{15}$ Demonic legends have only a final formula like that was a water spirit (when in the course of the tale the nature of the demon is not 
clarified, the teller sometimes would not say it at all, thus making one of the listeners to identify the demon). ${ }^{16}$ Even the sacred legend, a very prestigious genre, is quite simple stylistically; it practically does not differ from everyday speech (with the exception of natural differences that distinguish the monological speech from the dialogue).

In the versified genres, it is the nature of the verse itself that plays the role of the main feature. To avoid the technical definitions and rather redundant polemics, ${ }^{17}$ I will just define the verse of epics as bylina verse and describe it as a recitative (predominantly) three-stressed verse with the dactylic ending ${ }^{18}$ as opposed to song verse, i.e. various kinds of verse (different from the epic one) used in sung genres. These definitions are quite sufficient for our purpose.

All bylinas are composed in bylina verse,$^{19}$ and that is the only genre entirely composed in this verse. The historical songs differ by chronology; the elder songs, e.g., on the Ivan the Terrible and his son, are sung in bylina verse, while the younger songs are usually in song verse. Ballads can be very close to bylina in their poetics, so that some texts are difficult to define as bylina or ballad, these texts are naturally recited in bylina verse, but many other ballads are sung in one of song verses and could be close to lyric song poetics. Dukhounye stikhi (spiritual verses) are usually composed in bylina verse, although in dukhounye stikhi the two-syllable clause is much more frequent than in bylina ${ }^{20}$ (and, it seems, sometimes their melodies could be more songlike), but that is true only for "elder" spiritual verses. As for the younger, lyric verses, they are sometimes sung in bylina verse like the elder ones, but can be composed in purely song verse as well. For skomoroshina, the situation depends on its definition, skomoroshina sensu stricto, the parodic epic, naturally was composed in bylina verse, otherwise it could not be a parody of bylina. ${ }^{21}$ But in a broader sense, when other comic narrative songs are included, they are not necessarily sung in bylina verse and can be composed in song verse as well. Thus all genres beside bylina could be composed in bylina verse or song verse, while bylinas could be only in bylina verse.

Those are the principles uniting the narrative segments of our genre space. I would like to mention one more symmetrical relationship that pertains only partially to the narrative area. This is the symmetry in the sphere of nonversified genres. As I have noted above, some genres tend to diminish stylistic distinction, so that they do not conspicuously differ from everyday speech. Moreover, some kinds of texts, not only gossip or rumors, but some kind of legends, especially demonic ones, can be, so to speak, submerged in the flow of speech. They can be retold on some special occasion, even in ritual contexts (e.g., demonic legends, especially with a scary main motif, must be told on Yuletide and on some other calendar rituals) but are also told just casually, 
because of a chancy association..$^{22}$ This "dissolving" of a narrative text in the speech flow finds its counterpart on the opposite pole of non-verse genres, in proverbs and by-words. By these two words, I translate the Russian terms poslovica and pogovorka, both meaning 'proverbs' but the first denoting the paroemia consisting of the whole sentence, while the second making only an incomplete sentence, like a phraseological unit, so that it cannot be used without adding some syntactic context, for example, a subject for the verbal idiom, or a verb for the substantive one. These genres even more than the abovementioned short stories are dissolved in the usual, everyday speech. But for proverbs, the situation is even more interesting. Many scholars, including, for instance, Roman Jakobson, mentioned that the proverb coincides with the largest unit of the language (namely, sentence) being at the same time the minimal folklore text. Grigory L. Permiakov claimed that there exists paroemiological level or stratum of language, somewhere above the level of phraseology. If so, in the non-verse part of the genre space, we have the axis where on one pole we can see the short narrative genres dissolved in the flow of speech, and on the opposite pole, proverbs and by-words not only, in a similar way, dissolving in speech (in a syntagmatic aspect) but at the same time (in a paradigmatic aspect) merging with the language (speech and language are used here, of course, in the sense of de Saussure's parole and langue), thus surpassing the border between the language and folklore.

\section{COMMENTS}

1 In accordance with Russian tradition I use the term folklore in the sense of 'folk or oral literature'.

2 The whole description has been published in Russian (Levinton 1998). Some new arguments have been added in the present work.

${ }^{3}$ In fact, I am not interested in borders at all. It is the borderlines that usually cause most of confusions and misunderstandings in all discussions of genres. The best part (I mean only quantity, of course) of criticism leveled against the notion of genre, or any specific genre classification, would refer to "gray areas", the borderline examples, the cases that can be more or less reasonably called unclassifiable. Of course, there are cases when one cannot say if the text under analysis is an epic retold in prose or a heroic fairy tale, or, in other cases, if it is a fairy tale sung in epic verse or an epic song with the main motif influenced by the fairy tale. Similarly, difficulties can arise in classifying the text as an epic song or a ballad. But to evaluate the theoretical importance of such difficult counterexamples, one should bear in mind that they comprise about 3, maximum 5 per cent of the whole epic and tale material, while in all the other cases no such questions arise and any second-year student would easily identify an epic song or a fairy tale (in case of ballads vs. epic songs we 
perhaps should increase the number of borderline cases up to 5 or 6 per cent). It is the kernel of the genre, not its borderline cases that should be analyzed.

${ }^{4}$ I must cite one exception known to me, the genre we can perceive (at least from the point of view of modern synchronic perception) only as verse, but which never has any melody, that is count-down rhymes used for distributing parts among players before a game. The main feature of such texts is their pronounced word rhythm, by which players count. The melody would spoil this effect (though I do not know whether similar genres in other traditions could be sung). Probably the fact that this genre belongs to a very specific subsystem, that of children's folklore, is relevant here.

5 This opposition sung vs. non-sung resembles the situation in early and medieval Russian literature: as scholars studying the history of Russian verse claim, for that period there could not be found an opposition of verse vs. prose, but rather the text to be read (told) vs. the texts to be sung. The former class comprises narrative or rhetorical genres, as well as oral tales; the latter contains folk songs (including epics) and church prayers and hymns (see Gasparov 1997a).

6 These two types of descriptions significantly resemble two classical approaches to phonology: the universal system of DF in later works of Jakobson (with Fant and Halle) vs. language-specific systems in Trubetzkoy's works.

${ }^{7}$ Attempts to find chastushka in the 18th century cannot be taken seriously. Even less possible would be any earlier date because of the constructive role of rhyme in chastushka.

8 Actually this term covers two types of songs: the so-called "elder spiritual songs", that are narrative, and "younger ones" where narrative element is reduced or altogether absent. The hero of such songs can be not a personage of the sacred history, but rather an "everyman"; some of these texts, when completely devoid of narrative element, resemble psalms of prayers. The "younger" type in general should be classified with songs of the group (1).

9 Skomoroshina is derived from the word skomorokh 'jester', 'clown', 'jongleur'. In the narrow sense skomoroshina means only parodic epics, in broader sense it includes some other kinds of comic narrative songs, not necessary parodying bylinas (see Ivleva 1972).

${ }^{10}$ For a detailed genre classification of paroemias (see Permiakov 1979 and his other works).

${ }^{11}$ I should explain to those not acquainted with Russian material at first hand that curiously enough that too is the tradition of folklore scholars not of performers who called this genre starina (literally 'old [story]') etymologically connected to Serbian genre term starinske pjesme.

${ }^{12}$ One can put quite a legitimate question of versified counterpart to formula tales, the last section of Aarne-Thompson. I am afraid the case is too complicated to give a clear-cut answer. Some tale types belonging to the class of formula tales can take the form of songs (without losing its cumulative structure), or even a dramatized game. These songs can be cited as counterpart to formula tales but should we classify them with songs or with tales? Probably, some analogue to formula tales still could be found among some ritualized form of children songs, but I have not yet found such examples. 
${ }^{13}$ Actually I believe such a claim would be false, since the non-versified legends and spiritual verse have quite a different repertoire of motifs (or types). Russian legends, at least oral texts collected and published in the 19th and early 20 th century, usually do not include hagiographic motifs, there are no saints' vitae among them (the saints in these stories can appear only as already canonized characters), while spiritual verses have several types of that kind (St Alexis, St George, etc.). Legends avoid any plots that involve Christ (in His life) and Our Lady, while spiritual verses describe Crucifixion, the Virgin's dream prophesizing it, etc. Probably, the only motif pertaining to Sacred Times (i.e., the time of Old or New Testaments) is the motif of Creation (God creates the World while Devil creates some of its negative features, like mountains, snakes, etc.).

14 The only dissenting opinion was formulated by Aleksandr I. Nikiforov (1938), who claims that ornamentation does not belong to any textual class of tales but to the type of storyteller.

15 This is an interesting indication that this feature has no correlation to traditional or more or less innovative genres.

${ }^{16}$ This practice has been observed and described by my student Elena Migunova.

${ }^{17}$ Quite different definitions of epic verse can be found in many works by James Bailey who gives detailed descriptions of some song meters as well (see, e.g., Bailey 1993).

${ }^{18}$ For a more detailed description see Jakobson 1966; Levinton 1996; Gasparov 1997b.

19 There is a well-known single exception, bylina "Vavilo's journey with minstrels" as performed by Maria Krivopolenova, which has the stress on the penultimate syllable of each line.

${ }^{20}$ These and some other more subtle differences have been noted in the above-mentioned paper by Mikhail L. Gasparov (1997b: 84-85, 89-94).

${ }^{21}$ By the way, the collector applied the term skomoroshina to the above-mentioned bylina on Vavilo (for thematic reasons, because skomorokhi 'minstrels' figure there).

${ }^{22} \mathrm{Cf}$. very similar double way of telling jokes in modern urban oral tradition: namely "swapping jokes" for some time or telling just one joke pertaining to the theme of a conversation.

\section{REFERENCES}

Bailey, James 1993. Three Russian Lyric Folk Song Meters. Columbus (Ohio): Slavica Publishers.

Gasparov, Mikhail L. 1989. Ocherk istorii evropeiskogo stikha (The concise history of European verse). Moscow: Nauka.

Gasparov, Mikhail L. 1997a. Oppozicija "Stikh - Proza" i Stanovlenie Russkogo Literaturnogo Stikha (Opposition "verse vs. prose" and the evolvement of the Russian literary verse). In: Mikhail L. Gasparov, Izbrannye Trudy (Selected Works), Vol. 3: $O$ Stikhe (On verse). Jazyk. Semiotika. Kul'tura (Language. Semiotics. Culture). Moscow: Jazyki russkoi kultury, pp. 40-53. 
Gasparov, Mikhail L. 1997b. Russkii narodnyi stikh i ego literturnye imitacii (Russian folk verse and its literary imitations). In: Mikhail L. Gasparov. Izbrannye Trudy (Selected Works), Vol. 3: O Stikhe (On Verse). Jazyk. Semiotika. Kul'tura (Language. Semiotics. Culture). Moscow: Jazyki russkoi kultury, pp. 54-131.

Ivleva, Larisa M. 1972. Skomoroshina (Obshchie problemy izucheniia)(Skomoroshina: General problems of studying). In: Boris N. Putilov \& Vera K. Sokolova (eds.) Slavianskii Folklor (Slavic Folklore). Moscow: Nauka, pp. 110-124.

Jakobson, Roman 1966. Slavic Epic Verse. Selected Writings, Vol. 4: Slavic Epic Studies. The Hague: Mouton de Gruyter, pp. 414-464.

Levinton Georgiy A. 1998. Zamechaniia o Zhanrovom Prostranstve Russkogo Folklora (Notes on the genre space of Russian folklore). In Vera D. Ken (ed.). Sud'by Tradicionnoi Kul'tury: Sbornik statei i Matrialov Pamiati Larisy Ivlevoi' (The ways of traditional culture: In Memoriam Larisa Ivleva). St Petersburg: Dmitry Bulanin Publishers, pp. 56-71.

Levinton, Georgiy A. 1996. Further Notes on Trubetzkoy's Verse Theory. Elementa: Journal of Slavic Studies and Comparative Cultural Semiotics, Vol. 2: Nos. 3-4, pp. $285-294$.

Nikiforov, Aleksandr I. 1938. Zhanry russkoi skazki (Genres of Russian folk-tale). Uchenye Zapiski Len. Gos. Ped. In-ta Fakul'tet yazyka i literatury (Works of Leningrad State Pedagogical Institute, Dept. of Language and Literature), Vol. 1, pp. 233-259.

Permiakov, Grigory L. 1979. From Proverb to Folk-Tale: Notes on the General Theory of Cliché. Studies in oriental folklore and mythology. Moscow: Nauka Publishers.

Propp, Vladimir Ia. 1976a. Principy klassifikacii folklornykh zhanrov (Principles of folklore genres classification). In: Vladimir Ia. Propp. Folklor i Deistvitel'nost': Izbrannye stat'i (Folklore and reality: Selected writings). Issledovaniia no fol'kloru i mifologii Vostoka (Researches of oriental folklore and mythology). Moscow: Nauka, pp. 3445.

Propp, Vladimir Ia. 1976b. Zhanrovyi sostav russkogo folklora (Genre repertory of Russian folklore). In: Vladimir Ia. Propp. Folklor i Deistvitel'nost': Izbrannye stat'i (Folklore and reality: Selected writings). Issledovaniia no fol'kloru i mifologii Vostoka (Researches of oriental folklore and mythology). Moscow: Nauka, pp. 46-82.

Revzin, Isaak I. 1975. K Obshesemioticheskomu Istolkovaniiu Trekh Postulatov Proppa (Analiz Skazki i Teoriia Sviaznosty Teksta)(On the general semiotic interpretation of Propp's Three Postulates (The analysis of folk-tale and the theory of text coherency)). In: Eleazar M. Meletinskii \& Sergei Iu. Nekliudov, (eds.). Tipologicheskie Issledovaniia po Folkloru: Sbornic Statei pamiati V. Ia. Proppa (Typological studies in folklore: In Memoriam Vladimir Ia. Propp). Issledovaniia no fol'kloru i mifologii Vostoka (Researches of oriental folklore and mythology). Moscow: Nauka, pp. 77-91.

Toporov, Vladimir N. 1998. Predistoriia Literatury u Slavian: Opyt rekonstrukcii: (Vvedenie $k$ kursu istorii slavianskikh literatur)(Prehistory of literature among Slavs: Essay in reconstruction (Introduction to the course of Slavic Literatures). Moscow: Russian State University in Humanities. 